\title{
Immunocytochemical and Morphological Evidence for Intracellular Self-Repair as an Important Contributor to Mammalian Hair Cell Recovery
}

\author{
J. Lisa Zheng, ${ }^{1}$ Gilbert Keller, ${ }^{2}$ and Wei-Qiang Gao ${ }^{1}$ \\ Departments of ${ }^{1}$ Neuroscience and ${ }^{2}$ Pharmacokinetics and Metabolism, Genentech, South San Francisco, \\ California 94080
}

Although recent studies have provided evidence for hair cell regeneration in mammalian inner ears, the mechanism underlying this regenerative process is still under debate. Here we report immunocytochemical, histological, electron microscopic, and autoradiographic evidence that, in cultured postnatal rat utricles, a substantial number of hair cells can survive gentamicin insult even their stereocilia are lost. These partially damaged hair cells can survive for a prolonged time and regrow the stereocilia. Although the number of stereocilia-bearing hair cells increases over time after gentamicin insult, hair cell and supporting cell numbers remain essentially unchanged. Tritiated thymidine autoradiography and bromodeoxyuridine immunocytochemistry of the cultures demonstrate that cell prolifer- ation in the sensory epithelium is very limited and is far below the number of recovered hair cells. Furthermore, terminal deoxynucleotidyl transferase-mediated biotinylated UTP nick end labeling analysis indicates that gentamicin-induced apoptosis in the sensory epithelium occurs mainly during a $2 \mathrm{~d}$ treatment period, and additional cell death is minimal 2-11 $\mathrm{d}$ after treatment. Considered together, intracellular repair of partially damaged hair cells can be an important contributor to spontaneous hair cell recovery in mammalian inner ears.

Key words: hair cells; supporting cells; regeneration; selfrepair; apoptosis; proliferation; vestibular; utricle; inner ear; gentamicin; autoradiography
Hair cells are mechanosensory receptors located in the cochlea and vestibular end organs that transduce sound and motion signals into electrical impulses (Hudspeth, 1989, 1997; Pickles and Corey, 1992) that can be relayed to the brain by cochlear and vestibular ganglion neurons. Aminoglycoside antibiotics, loud sounds, aging, and various diseases can cause hair cell loss, resulting in hearing and balance impairments (Dublin, 1976; Baloh and Honrubia, 1990; Nadol, 1993). Studies over the last decade have demonstrated that hair cells lost because of injury can be replaced by production of new hair cells in chick ears and in lower vertebrates (for review, see Cotanche and Lee, 1994; Corwin and Oberholtzer, 1997; Stone et al., 1998). Experiments using DNA synthesis markers in chicks (Corwin and Cotanche, 1988; Ryals and Rubel, 1988; Stone and Cotanche, 1994; Stone et al., 1996; Warchol and Corwin, 1996) and time-lapsed recording in axolotls (Balak et al., 1990; Jones and Corwin, 1996) have provided evidence that supporting cell proliferation is an early event, and supporting cells are the progenitors for the generation of new hair cells after injury. However, recent studies in chicks and frogs show that new stereocilia-bearing hair cells can appear in the inner ear sensory epithelium after injury in the presence of a mitotic inhibitor, demonstrating an involvement of a nonproliferative regeneration process as well (Adler and Raphael, 1996;

\footnotetext{
Received Nov. 9, 1998; revised Dec. 28, 1998; accepted Jan. 7, 1999.

We thank Patti Tobin for assistance in paraffin sections, Linda Rangell for assistance in electron microscopy, and Gretchen Frantz for assistance in autoradiography. We also thank Wayne Anstine for preparation of the figures, Leonie Meima for critical reading of this manuscript, and Jeffrey T. Corwin for his thoughtful scientific input and helpful discussion.

Correspondence should be addressed to Dr. Wei-Qiang Gao, Department of Neuroscience, MS \#72, Genentech, 1 DNA Way, South San Francisco, CA 94080. Copyright (C) 1999 Society for Neuroscience $0270-6474 / 99 / 192161-10 \$ 05.00 / 0$
}

Baird et al., 1996; Roberson et al., 1996; Adler et al., 1997; Steyger et al., 1997).

Increasing evidence suggests that hair cell regeneration can also occur in mammalian vestibular end organs after ototoxic damage (Forge et al., 1993; Warchol et al., 1993; Tanyeri et al., 1995; Yamane et al., 1995; Zheng and Gao, 1997). However, the mechanisms underlying this regenerative process in mammals have been under debate because the rate of supporting cell proliferation is very low and does not appear to match the number of recovered hair cells (Rubel et al., 1995; Warchol et al., 1995; Li and Forge, 1997). In addition to the models of supporting cellmediated production of new hair cells, experiments with cultured rodent cochlear explants (Sobkowicz et al., 1992, 1995, 1997) and utricular epithelial sheets (Zheng and Gao, 1997) suggest the possibility of self-repair of the stereociliary bundles of partially damaged hair cells.

To determine the primary mechanism of mammalian hair cell regeneration and recovery, we investigated hair cell regeneration in postnatal rat utricles in vitro and used the hair cell marker anti-calretinin antibody (Dechesne et al., 1994; Zheng and Gao, 1997). We performed quantitative analysis of hair cells and supporting cells at various time points after gentamicin treatment. We found that a substantial number of hair cells survived gentamicin treatment although their stereociliary bundles were lost. The number of surviving hair cells remained relatively unchanged for a prolonged time after gentamicin treatment. Although the number of stereociliary bundle-bearing hair cells increased over time after gentamicin insult, the number of supporting cells did not decrease significantly. We also confirmed by ultrastructural examination the presence of partially damaged hair cells that do not bear stereociliary bundles immediately after 
gentamicin treatment. We found that gentamicin-induced apoptosis in the sensory epithelium occurred mainly during the $2 \mathrm{~d}$ treatment period, and prolonged apoptosis was minimal after gentamicin treatment. Moreover, the number of proliferative cells in the sensory epithelium was far below the number of recovered hair cells. Thus, these observations provide both immunocytochemical and morphological evidence that intracellular selfrepair serves as a major mechanism for spontaneous rat vestibular hair cell recovery.

\section{MATERIALS AND METHODS}

Organotypic cultures of utricle whole mounts. Utricular explants were dissected from postnatal day 3 (P3) rats and embedded in $20 \mu \mathrm{l}$ of freshly made collagen in $35 \mathrm{~mm}$ Nunc (Roskilde, Denmark) tissue culture dishes, as previously described (Zheng and Gao, 1996). Rat tail collagen (type I, $3.76 \mathrm{mg} / \mathrm{ml}$ formulated in $0.02 \mathrm{~N}$ acetic acid; Collaborative Research, Bedford, MA) was mixed with $10 \times$ basal medium Eagle's (BME) medium and 2\% sodium bicarbonate in a ratio of 9:1:1 and placed on ice just before use. The collagen containing the utricular explants was placed in a $37^{\circ} \mathrm{C}$ incubator supplied with $5 \% \mathrm{CO}_{2}$ for $5-10$ min until it gelled, and $2 \mathrm{ml}$ of serum-free medium [BME plus serum-free supplement (Sigma, St. Louis, MO; I-1884), 1\% BSA, 2 mm glutamine, $5 \mathrm{mg} / \mathrm{ml}$ glucose, $25 \mathrm{ng} / \mathrm{ml}$ fungizone, and $10 \mathrm{U} / \mathrm{ml}$ penicillin] (Zheng et al., 1995) was added to the dish to cover the explants. The culture medium was changed, and gentamicin was added to the culture on the second day [ $2 \mathrm{~d}$ in vitro (2 DIV)]. The cultures were either fixed after $2 \mathrm{~d}$ of gentamicin $(1 \mathrm{~mm})$ treatment with $4 \%$ paraformaldehyde in $0.1 \mathrm{M}$ phosphate buffer, $\mathrm{pH} 7.4$, for $40 \mathrm{~min}$, or returned to normal, gentamicinfree medium containing $5 \mu \mathrm{g} / \mathrm{ml}(15 \mu \mathrm{M})$ aphidicolin, a mitotic inhibitor, and maintained for an additional 7-11 d before they were fixed and labeled with phalloidin and an antibody against calretinin. Parallel cultures maintained in normal serum-free medium for 4 or $15 \mathrm{~d}$ without receiving gentamicin treatment were used as controls. To determine cell proliferation in the cultures, bromodeoxyuridine (BrdU) (1:1000; Amersham cell proliferation kit; Amersham, Arlington Heights, IL) or aphidicolin and BrdU was added to the cultures after $2 \mathrm{~d}$ gentamicin treatment and was continuously present for an additional $11 \mathrm{~d}$.

Cryostat sections, immunocytochemistry, and terminal deoxynucleotidyl transferase-mediated biotinylated UTP nick end labeling. The utricular whole-mount cultures were fixed in $4 \%$ paraformaldehyde in $0.1 \mathrm{M}$

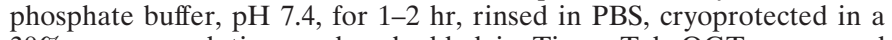
$30 \%$ sucrose solution, and embedded in Tissue-Tek OCT compound (Miles). Twenty micrometer serial sections were cut, collected on microscopic slides, and stored at $-20^{\circ} \mathrm{C}$ for immunocytochemistry. Cryostat sections were blocked with $10 \%$ normal goat serum (NGS) in PBS containing $0.1 \%$ Triton $\mathrm{X}-100$ for $20 \mathrm{~min}$ and then incubated with anti-calretinin antibody (1:200; Chemicon, Temecula, CA) diluted in PBS containing $3 \%$ normal goat serum and $0.1 \%$ Triton $\mathrm{X}-100$ overnight at $4^{\circ} \mathrm{C}$. Texas Red-conjugated secondary antibody (1:70; Cappel, Cochranville, PA) was used to reveal the labeling patterns. Calretinin immunostaining of the whole-mount utricular explants were processed in the same way as the cryostat sections except that the preparations were also double-labeled with a phalloidin-FITC conjugate $(0.5 \mu \mathrm{g} / \mathrm{ml}$ in PBS) for $40 \mathrm{~min}$. For BrdU immunostaining, cultures were treated with $2 \mathrm{~N} \mathrm{HCl}$ for $40 \mathrm{~min}$ at room temperature after fixation and washed in $0.2 \mathrm{M}$ phosphate buffer, $\mathrm{pH} 7.4$, and PBS. The cultures were incubated with an anti-BrdU monoclonal antibody (1:40; Becton Dickinson, Mountain View, CA) in PBS containing $0.1 \%$ Triton X-100 and 3\% NGS overnight at $4^{\circ} \mathrm{C}$, followed by incubation with FITC-conjugated goat anti-mouse (1:200, Vector Laboratories, Burlingame, CA) secondary antibody at room temperature for $45 \mathrm{~min}$. For terminal deoxynucleotidyl transferasemediated biotinylated UTP nick end labeling (TUNEL), utricular sections were processed with Boehringer Mannheim (Indianapolis, IN) In Situ Cell Death Detection kit (FITC-mediated) for $45 \mathrm{~min}$ at $37^{\circ} \mathrm{C}$, as described previously (Zheng and Gao, 1997). Labeled preparations were finally washed in PBS, mounted in Fluoromount-G (Southern Biotechnology Association) and viewed using a Zeiss Axiophot epifluorescent microscope with a 20 and $40 \times$ lens. Images were captured with Compix imaging systems using a cold red, green, and blue CCD camera.

Cell tracker green labeling. To confirm the viability of calretinin-positive hair cells in the utricular sensory epithelium, we used Cell Tracker green [5-chloromethylfluorescein diacetate (CMFDA); Molecular Probes, Eugene, OR], which labels all live cells in the culture. The utricular epithelial sheets containing essentially only hair cells and supporting cells were prepared from P3 rats (Corwin et al., 1996; Zheng and Gao, 1997; Zheng et al., 1997) recovered in culture for $2 \mathrm{~d}$ after plating and were treated with gentamicin $(1 \mathrm{mM})$ for $2 \mathrm{~d}$. The cultures were maintained for an additional $11 \mathrm{~d}$. CMFDA was then underlaid into the cultures and incubated at $37^{\circ} \mathrm{C}$ for $1 \mathrm{hr}$ (Zheng et al., 1998). The cultures were then fixed and double labeled with an anti-calretinin antibody, followed with a Texas Red-conjugated secondary antibody.

Paraffin sections and hematoxylin and eosin staining. The utricular whole-mount cultures were fixed in $10 \%$ neutral buffered formalin. The preparations were then washed, dehydrated in ascending graded alcohols, cleared in xylene, and embedded in paraffin. Serial $3 \mu \mathrm{m}$ paraffin sections of the preparations were cut with a microtome. The sections were processed with hematoxylin and eosin staining before they were dehydrated in ascending alcohols, cleared in xylene, and mounted in Permount.

Cell counts in cryostat and paraffin sections of utricular whole-mount cultures. To count calretinin-positive, BrdU-positive, or TUNELpositive cells from serial cryostat sections or hair cells, bundle-bearing cells, and supporting cells from paraffin sections of utricular wholemount cultures, we used an ocular grid in a Zeiss Axiophot microscope with a 20 and $40 \times$ lens. Only cells with a clearly defined nucleus were counted in the paraffin sections. Cells with a pyknotic or condensed nucleus were not counted. For cryostat sections, cell counts were performed from every serial sections by adjusting focusing planes in the microscope. For paraffin sections, cell counts were made from every other serial section. Because the nuclear diameter of hair cells is $\sim 4-6$ $\mu \mathrm{m}$, collecting cell numbers from every other section allowed us to avoid double counting. Although calretinin-labeled cells could be easily counted from the serial cryostat sections, identity of the cells in the paraffin sections was determined by their location of cell somata and nuclei in the epithelium. Generally, hair cells have large nuclei, pear- or barrel-shaped morphology, and are located in the superficial layers of the sensory epithelium. In contrast, supporting cell nuclei are located in the deep layer of the sensory epithelium. In most cases, hair cell nuclei are distributed in the lumenal 2 layers, whereas supporting cell nuclei are located in the deep layer of the sensory epithelium. Cells located in the singular layer of the peripheral epithelium were judged as nonsensory epithelial cells. Cell counts obtained in control cultures might have been underestimated because of the high density of hair cells. Only the cells that displayed clearly defined stereociliary bundles were counted as stereociliary bundle-bearing hair cells. It is possible that we might have equally underestimated the total numbers of stereociliary bundle-bearing cells in all experimental groups because of the limited structural preservation and cutting angles of the paraffin sections. Data collected from each experimental group, as indicated in the figure legends (with or without gentamicin treatment), are expressed as mean \pm SEM. ANOVA Bonferroni-corrected test was used for statistical analysis.

Electron microscopy. The utricular whole-mount cultures were fixed with a mixture of freshly made $2 \%$ glutaraldehyde and $2 \%$ paraformaldehyde in $0.1 \mathrm{M}$ cocodylate buffer, $\mathrm{pH}$ 7.4. Specimens were post-fixed in $1 \%$ osmium, dehydrated in ascending grade alcohols, cleared in propylene oxide, and embedded in epoxy resin. Thin sections were cut, stained with aqueous uranyl acetate and lead citrate, and examined in a Phillips CM12 electron microscope.

Autoradiography. Tritiated thymidine $(1 \mu \mathrm{Ci} / \mathrm{ml})$ was added to the cultures at the time when gentamicin was introduced and was continuously present for an additional $11 \mathrm{~d}$ after $2 \mathrm{~d}$ gentamicin $(1 \mathrm{mM})$ treatment. In these autoradiography experiments, no aphidicolin was included in the culture medium. The preparations were fixed in $10 \%$ neutral buffered formalin and processed for paraffin sections. After paraffin sections were collected on slides, the slides were deparaffinized through three changes of xylene (5 min each) and descending graded ethanols $100(2 \times), 95(2 \times)$, and $70 \%(1 \times)(1 \mathrm{~min}$ each $)$, rinsed in water, redehydrated through 70 , 95, and $100 \%$ ethanols (1 min each) and air-dried. The slides were then dipped in Kodak (Eastman Kodak, Rochester, NY) NTB-2 nuclear track emulsion (diluted 1:1 with doubledistilled $\mathrm{H}_{2} \mathrm{O}$ ) at $42^{\circ} \mathrm{C}$, air dried in a light-tight drawer at room temperature, boxed in light-tight boxes, and exposed for another $6 \mathrm{~d}$ at $4^{\circ} \mathrm{C}$. The slides were developed in Kodak D-19 developer (diluted 1:1 with water, for $3 \mathrm{~min}$ at $12^{\circ} \mathrm{C}$ ), rinsed in water, and fixed in GBX fixer and replenisher (diluted 1:5 with water, for $3 \mathrm{~min}$ at $12^{\circ} \mathrm{C}$ ). The slides were counterstained with hematoxylin and eosin and examined in a Zeiss Axiophot microscope with a 20 and $40 \times$ lens. 

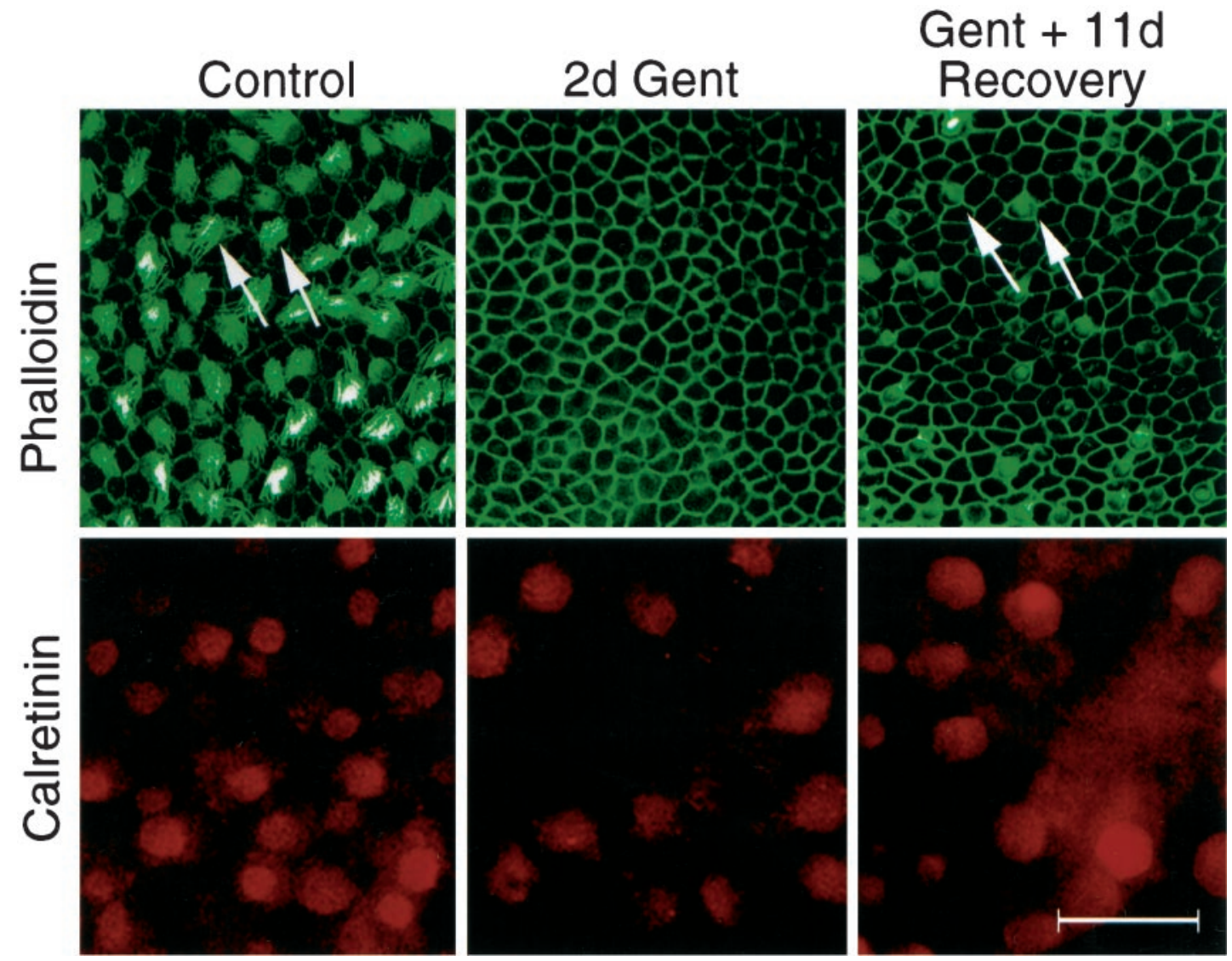

Figure 1. Double labeling of P3 utricular explant cultures with phalloidin (green) and anti-calretinin antibody (red). The phalloidin-labeling and calretinin-immunostaining images were taken at different focal planes. Note that although $2 \mathrm{~d}$ gentamicin ( $1 \mathrm{~mm})$ treatment results in a loss of virtually all stereociliary bundles (phalloidin labeling), a substantial number of hair cell somata remains (calretinin labeling). Arrows indicate the stereociliary bundles. After $11 \mathrm{~d}$ recovery after gentamicin treatment, some stereociliary bundles begin to reappear, and they are much smaller than those in 4 DIV control cultures (arrows). Scale bar, $30 \mu \mathrm{m}$.

\section{RESULTS}

\section{A substantial number of hair cells in utricular whole- mount cultures survive gentamicin treatment although their stereociliary bundles are lost}

When P3 rat utricular explants were dissected and cultured in three-dimensional collagen gels in serum-free medium, virtually all hair cells survived. The majority of hair cells maintained their stereociliary bundles, as demonstrated by phalloidin-FITC and anti-calretinin antibody double labeling (Dechesne et al., 1994; Zheng and Gao, 1997). While phalloidin staining showed the stereociliary bundles of hair cells, anti-calretinin antibody labeled the entire hair cell bodies (Fig. 1). When the cultures were treated with gentamicin for $2 \mathrm{~d}$ at $1 \mathrm{~mm}$, a concentration that is in the range used by others (Warchol et al., 1993; Li and Forge, 1995), most of the stereociliary bundles disappeared, and supporting cells had a polygonal morphology as revealed by phalloidin labeling (Fig. 1). However, double labeling the cultures with anticalretinin antibody revealed that, despite the lack of stereociliary bundles, a substantial number of hair cell somata survived gentamicin treatment and persisted for at least $11 \mathrm{~d}$, a time point when some stereociliary bundles were seen to reappear (Fig. 1). Although the number of remaining hair cell somata was lower than that of untreated control cultures, no apparent difference in the density of hair cell somata was observed between the cultures immediately after gentamicin treatment and the cultures maintained for an additional $11 \mathrm{~d}$ (Fig. 1). The stereociliary bundles in the cultures that were treated with gentamicin and allowed to recover for $11 \mathrm{~d}$ appeared much shorter than those in control cultures, and their number was smaller (Fig. 1). The presence of a substantial number of hair cell bodies positive for calretinin antibody was also seen when the cultures were treated with an even higher concentration of gentamicin, $3 \mathrm{~mm}(\sim 25 \%$ hair cells remained, see also Zheng and Gao, 1997). These observations indicate that a considerable portion of hair cells survive gentamicin treatment although their stereociliary bundles are lost.

Serial cryostat sectioning and calretinin immunocytochemistry were used to confirm the survival of hair cells and to quantify the numbers of remaining hair cells before and after gentamicin treatment. Anti-calretinin antibody-labeled surviving hair cells were evident in the cryostat sections of gentamicin-treated cultures (Fig. 2A). Quantitative analysis of calretinin immunostaining in the serial cryostat sections showed that, although gentamicin treatment resulted in degeneration of hair cells, $54 \%$ of the hair cells (1179.4.5 $\pm 55.6 ; n=7$; Fig. $2 B$ ) survived as compared with the control cultures maintained for $4 \mathrm{~d}(2192.7 \pm 143.8 ; n=$ 7). Equivalent numbers of surviving hair cells $(1283.5 \pm 69.6 ; n=$ 8 ) were observed in the cultures that were treated with gentamicin and maintained for an additional $11 \mathrm{~d}$ (Fig. 2B). The presence of a substantial number of calretinin-positive cells in the cultures that were allowed to recover indicates that the partially damaged hair cells can survive for a prolonged period of time, at least $11 \mathrm{~d}$ after gentamicin treatment. 

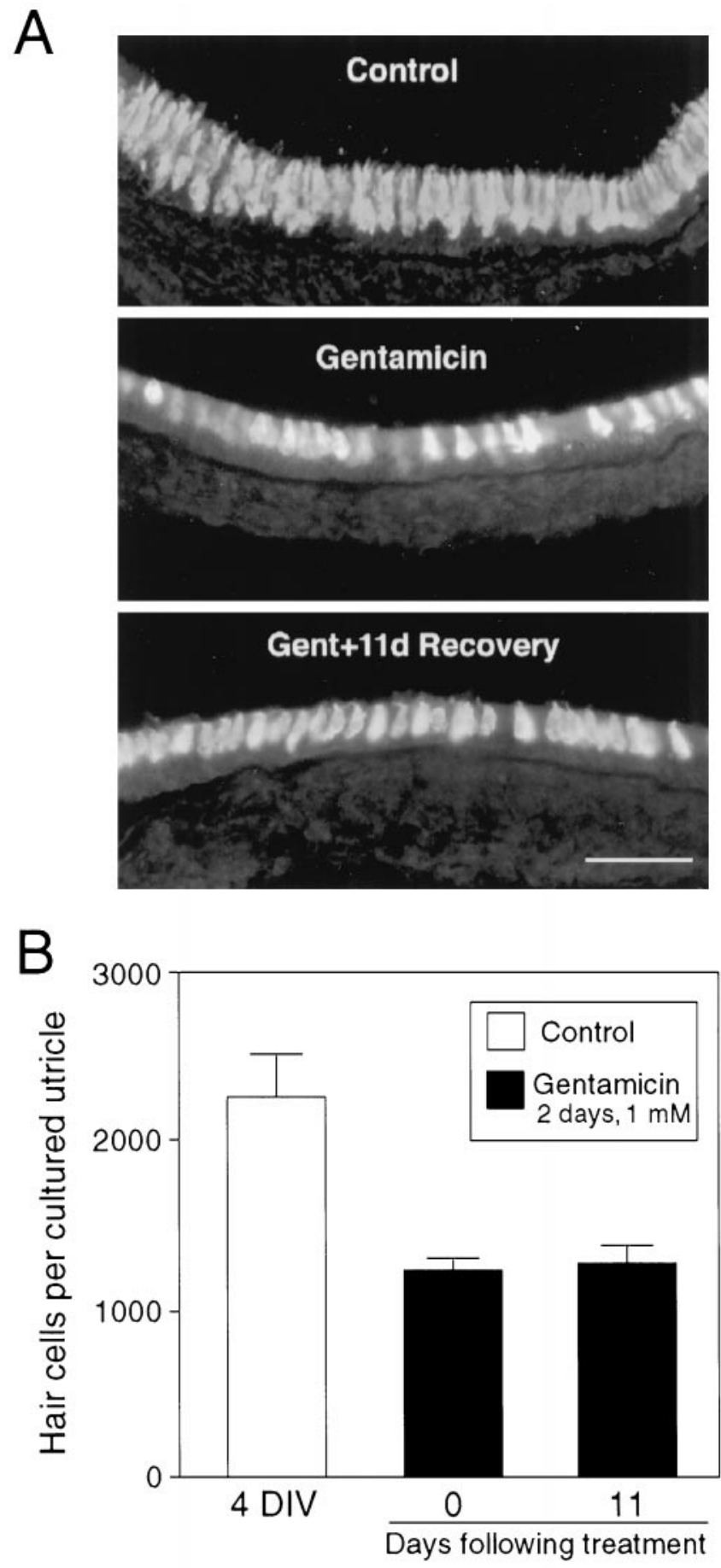

Figure 2. Calretinin immunostaining and cell counts of total hair cells in cryostat sections of utricular explant cultures. $A$, As shown in the wholemount cultures (Fig. 1), existence of hair cell somata is evident not only in 4 DIV control cultures, but also in gentamicin-treated cultures. $B$, Hair cell counts were performed in calretinin-immunostained serial cryostat sections of utricular explant cultures. Data were collected from seven 4 DIV control cultures, seven cultures immediately after gentamicin treatment, and eight recovery cultures, and are expressed as mean \pm SEM. Scale bar: $A, 50 \mu \mathrm{m}$.

The viability of calretinin-positive cells was also confirmed by double staining cultures of utricular epithelial sheets (Zheng and Gao, 1997), which provided a better cellular resolution than the utricular whole-mount cultures, with Cell Tracker green (CM-
FDA; from Molecular Probes; see Materials and Methods). CMFDA labels all live cells in the utricular epithelial sheet culture, including surviving hair cells and supporting cells. Virtually all calretinin-positive cells ( $\sim 50 \%$ of the hair cells survived $1 \mathrm{~mm}$ gentamicin treatment) in the cultures were double labeled with CMFDA (data not shown).

\section{Quantitative analysis of total hair cells, stereociliary bundle-bearing cells, and supporting cells in paraffin sections of the utricular whole-mount cultures}

Although calretinin immunocytochemistry of serial cryostat sections provided clear identification of hair cells and accurate counts of total remaining hair cells, cryostat sections do not provide optimal preservation of the cell structure and do not permit reliable analysis of stereociliary bundle integrity. To solve this problem, we prepared paraffin sections of the utricular wholemount cultures, which provided better structural preservation of stereociliary bundles. In control cultures maintained for $4 \mathrm{~d}$ in vitro (4 DIV), hair cells were densely packed in the superficial layers, and stereociliary bundles were present on most of the hair cells (Fig. $3 A$ ). In contrast, in the cultures fixed immediately after $2 \mathrm{~d}$ gentamicin treatment, stereociliary bundles were missing from the apical surface of the sensory epithelium (Fig. 3B), and because of the ototoxic damage there were more spaces in between the remaining hair cells. Although the morphology of the remaining hair cells was not as well defined as that of the control cultures, the nuclei of the remaining hair cells were evident. Some of the dead hair cells showed condensed nuclei, a typical sign of apoptosis (see below, Fig. 8). In the cultures treated with gentamicin and maintained for an additional $11 \mathrm{~d}$, the density of hair cells remained unchanged in the superficial layer of the epithelium as compared with the cultures immediately after gentamicin damage, but more stereociliary bundles were seen at the apical surface (Fig. 3D). The stereociliary bundles observed in the recovered cultures were much smaller or shorter than those of 4 DIV control cultures. Furthermore, the hair cells in the recovered cultures showed a better defined hair cell morphology and repositioned themselves in one layer, as a result of the structural recovery (Fig. 3D). Quantitative analysis of total hair cells, stereociliary bundle-bearing hair cells, and supporting cells at different time points after gentamicin treatment (Fig. 4) indicated that, while hair cell numbers remained essentially the same (immediately after gentamicin treatment, $1060.7 \pm 104.6, n=6 ; 7 \mathrm{~d}$ after gentamicin treatment, $1064.2 \pm 157.8, n=5 ; 11 \mathrm{~d}$ after gentamicin treatment, $1098.0 \pm 110.6, n=16$ ), the number of stereociliary bundle-bearing hair cells increased over time after gentamicin insult (immediately after gentamicin treatment, $66 \pm$ 15.6; $7 \mathrm{~d}$ after gentamicin treatment, $198.4 \pm 52.3, p<0.05$ as compared with the cultures immediately after gentamicin treatment; $11 \mathrm{~d}$ after gentamicin treatment, $418.1 \pm 81.5, p<0.01$ as compared with the cultures immediately after gentamicin treatment). Supporting cell numbers, however, did not decrease significantly (Fig. 4; 4 DIV control, 5406.2 $\pm 301.7, n=7 ; 15$ DIV control, $5205 \pm 220.6, n=7$; immediately after gentamicin treatment, $5854.3 \pm 149.8 ; 7 \mathrm{~d}$ after gentamicin treatment, $5231.7 \pm 292.4 ; 11 \mathrm{~d}$ after gentamicin treatment, $5481.0 \pm 410.9$, $p>0.05$, comparison between any of the gentamicin-treated groups and the 4 DIV control group; $p>0.05$, comparison between any two of the four groups). We also had control utricular whole mounts maintained in serum-free medium for $15 \mathrm{~d}$ in parallel to the cultures that were allowed to recover after gentamicin treatment. As shown in Figure $3 C$, the parallel 15 DIV 

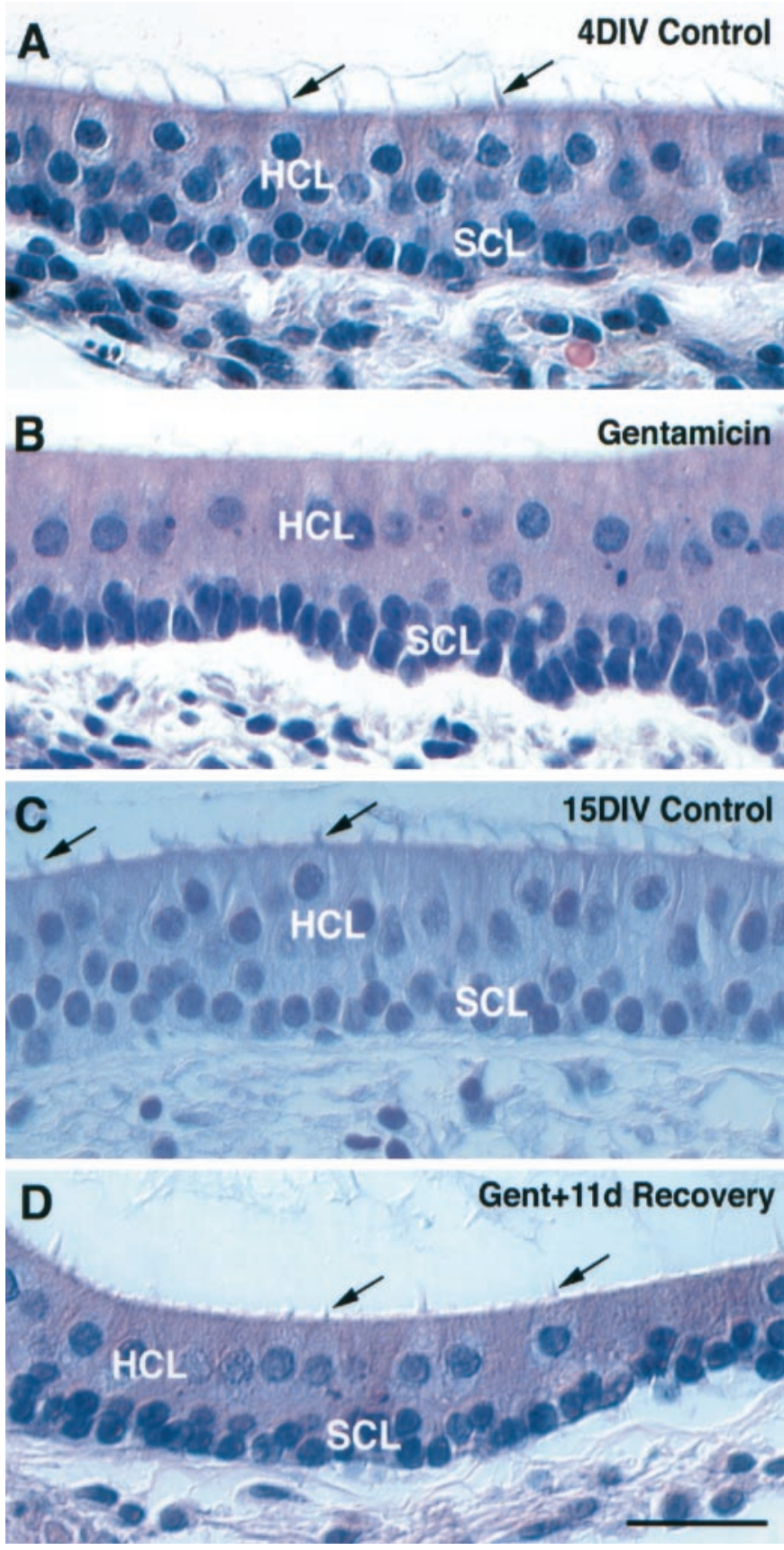

Figure 3. Paraffin sections of utricular explant cultures. Note that although virtually no stereociliary bundles are seen in the cultures immediately after $2 \mathrm{~d}$ gentamicin treatment that started in 2 DIV cultures $(B)$, some small stereociliary bundles appear in the recovered cultures $(D)$. Both $4(A)$ and 15 DIV $(C)$ control cultures show a good integrity of laminar layers, including hair cell layer $(H C L)$ and supporting cell layer $(S C L)$, and stereociliary bundle-bearing hair cells. The stereociliary bundles that reappeared (arrows) in the cultures treated with $1 \mathrm{~mm}$ gentamicin for $2 \mathrm{~d}$ and that were allowed to recover for additional $11 \mathrm{~d}(D)$ are smaller than those in the control cultures $(A, C)$. Scale bar, $30 \mu \mathrm{m}$.

control cultures showed normal laminar layers and hair cell and supporting cell morphology without obvious tissue deterioration (Fig. 3C; see also below, apoptosis was limited in these cultures, Fig. 8). No significant change was observed in the numbers of hair and supporting cells in the 15 DIV control cultures as compared with 4 DIV control cultures (Fig. 4). Because the anti-calretinin antibody does not recognize the antigen in paraffin sections, the identification of hair cells and supporting cells was mainly based on the location of their nuclei in the superficial or deep layers of the sensory epithelium. We used the criterion of "multiple cell layers versus one cell layer" (Lambert, 1994) to distinguish sensory epithelium from nonsensory epithelium at the border of the sensory epithelium. The peripheral, nonsensory epithelium contains only one cell layer. The percentage of surviving hair cells obtained in the analysis of the paraffin sections of these cultures was similar to the cell count from calretinin-positive cells in the cryostat sections, validating our identification of hair cells and supporting cells in the paraffin sections.

\section{Ultrastructural evidence for the presence of partially damaged hair cells that do not bear stereociliary bundles}

As ultrastructural analysis of the utricular whole-mount cultures provides a high resolution image of the stereociliary bundles, we processed two cultures from each of the three experimental groups, including 4 DIV control, immediately after $2 \mathrm{~d}$ gentamicin treatment, and $11 \mathrm{~d}$ recovery after gentamicin treatment, for electron microscopy. Five sample thin sections were collected from different regions of the plastic blocks and were examined. As shown in Figure 5, although stereociliary bundles were evident on virtually all hair cells in control cultures, some gentamicindamaged hair cells did not bear stereociliary bundles immediately after gentamicin treatment (Fig. 5, middle panel). These partially damaged, bundleless hair cells were still recognizable as hair cells based on their their morphological features, a continuous barrelshape cell body that reaches the apical surface of the sensory epithelium and contains a large nucleus at the basal pole. Examination of thin sections prepared from cultures maintained for $11 \mathrm{~d}$ after gentamicin treatment indicated that the majority of surviving hair cells displayed stereociliary bundles of various length (Fig. 5). We found that the percentage of stereociliary bundle-bearing cells observed in all three experimental groups at the ultrastructural level was higher than that in paraffin sections, as a result of better tissue preservation in plastic sections and higher image resolution of electron microscopy. The observation that the number of stereociliary bundle-bearing cells increases over time after gentamicin treatment suggests that the newly formed stereociliary bundles are most likely the result of repair of the partially damaged hair cells. In the recovered cultures (Fig. 5, right panel), the hair cells assumed a well defined, pear-shaped morphology, presumably because of vacated space in between the remaining hair cells in the superficial layer of the sensory epithelium and the structural recovery, as we also observed in the paraffin sections (Fig. 3). Therefore, the partially damaged hair cells not only survive, but also appear to retain the capacity to recover from damage induced by ototoxin.

\section{Cell proliferation is not a major contributor to mammalian hair cell recovery}

Although supporting cell proliferation appears to be a major contributor to hair cell regeneration in chick inner ears (for review, see Cotanche and Lee, 1994; Corwin and Oberholtzer, 1997; Stone et al., 1998), it is still under debate if cell proliferation is required for the reappearance of the stereociliary bundles in mammalian inner ears (Rubel et al., 1995; Warchol et al., 1995; Li and Forge, 1997). To address this issue, we included $15 \mu \mathrm{M}$ aphidicolin, an antimitotic agent, in the culture medium to block cell proliferation in all of the above-described experiments (see Materials and Methods). To determine how much cell prolifera- 


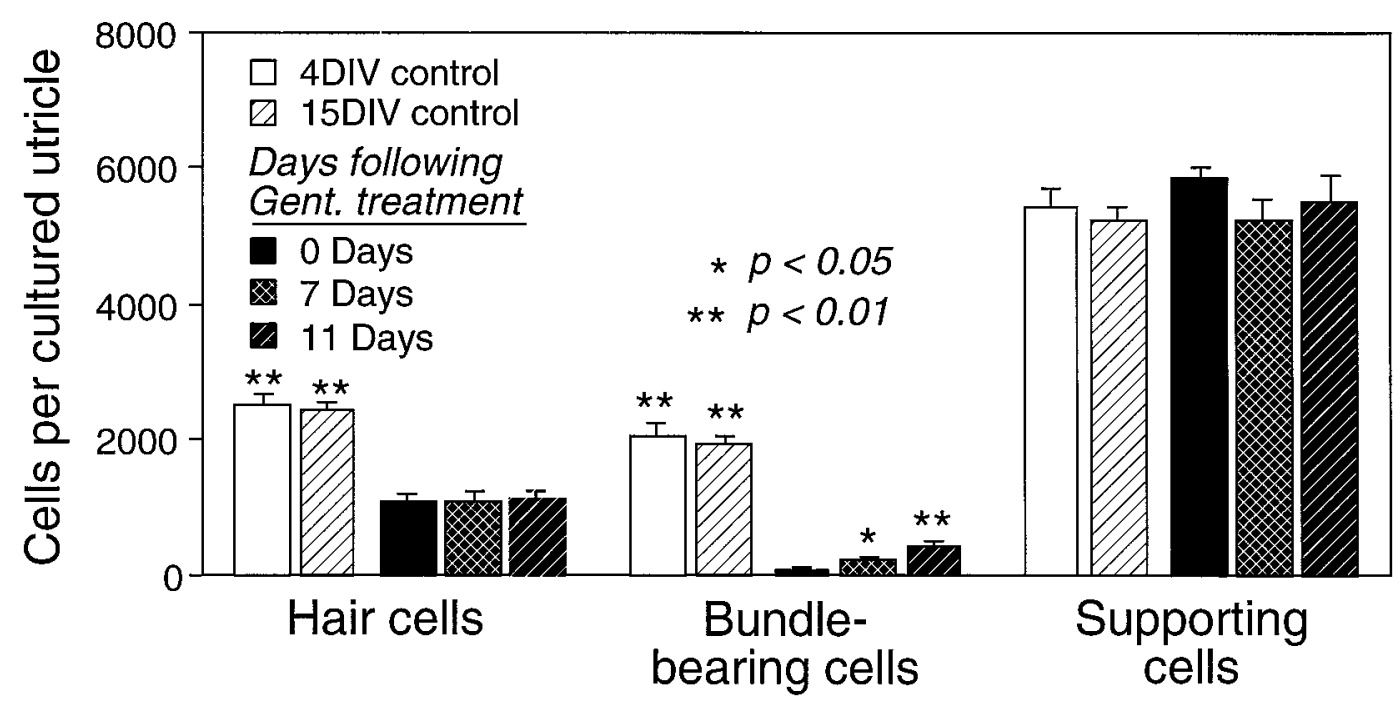

Figure 4. Cell counts of surviving hair cells, stereociliary bundle-bearing cells, and supporting cells in paraffin sections of the cultures at various time points after gentamicin treatment. Data were collected from seven 4 DIV control cultures, seven 15 DIV control cultures, six cultures immediately after $2 \mathrm{~d}$ gentamicin treatment, five cultures maintained for $7 \mathrm{~d}$ after $2 \mathrm{~d}$ gentamicin treatment, and 16 cultures maintained for $11 \mathrm{~d}$ after $2 \mathrm{~d}$ gentamicin treatment and are expressed as mean \pm SEM. Note that although there are no statistically significant differences in the numbers of supporting cells among all groups $(p>0.05)$, the numbers of stereociliary bundle-bearing cells increase significantly at 7 and $10 \mathrm{~d}$ after gentamicin treatment as compared with the cultures immediately treated with gentamicin for $2 \mathrm{~d}$. Asterisks in the figure indicate statistical significance as compared with the cultures immediately treated with $2 \mathrm{~d}$ gentamicin $(1 \mathrm{mM})$. There is no statistical significance $(p>0.05)$ in the numbers of remaining hair cells between 4 and 15 DIV control cultures or among the gentamicin-treated cultures, including immediately after gentamicin treatment, 7 , and $11 \mathrm{~d}$ after gentamicin treatment.
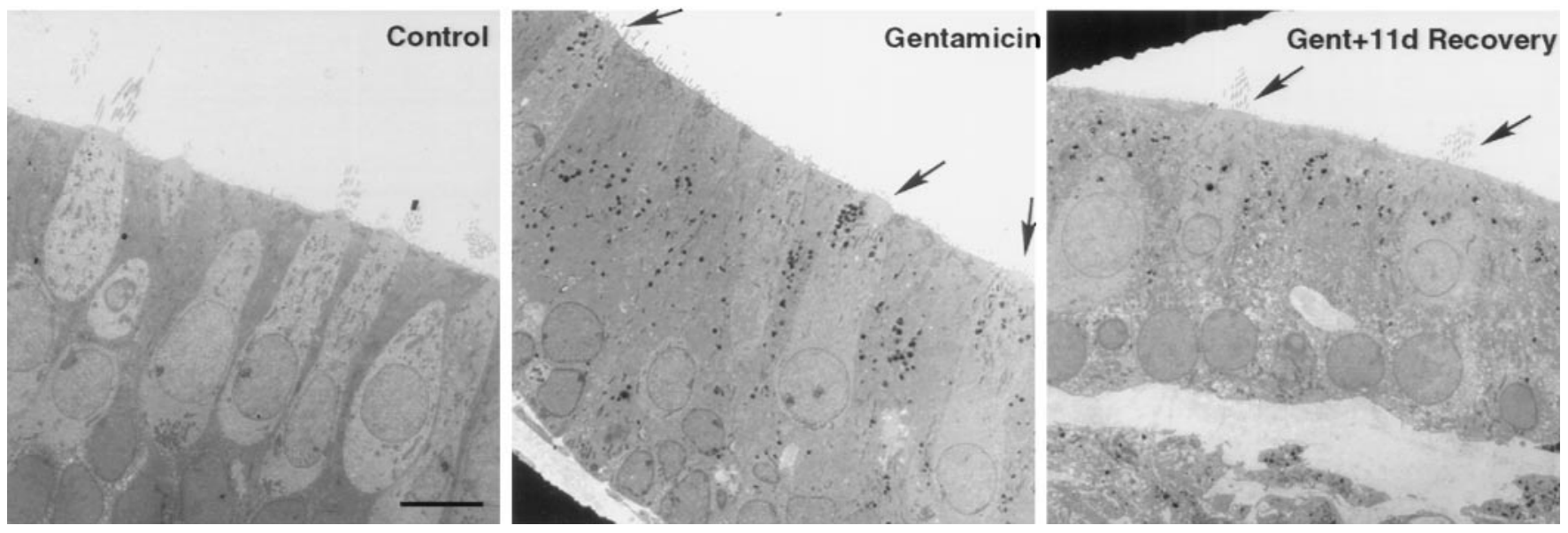

Figure 5. Electron microscopic evidence for the presence of partially damaged hair cells that do not bear stereociliary bundles immediately after gentamicin treatment. Arrows point to the region where stereociliary bundles should be expected. Many dark spots seen in middle and right panels are the result of gentamicin insult. Note that bundleless hair cells are seen in the cultures immediately after $2 \mathrm{~d}$ gentamicin treatment. Scale bar, $6 \mu \mathrm{m}$.

tion directly contributes to hair cell recovery and regeneration, BrdU or tritiated thymidine was added to gentamicin-treated cultures, and the cultures were maintained for an additional $11 \mathrm{~d}$. BrdU immunocytochemistry of the cultures revealed that there was limited cell proliferation in the sensory epithelium of 15 DIV control cultures (Fig. 6), which is consistent with published communications reporting that terminal mitosis of hair cell progenitors is mainly completed by birth (Ruben, 1967; Sans and Chat, 1982). We found that gentamicin treatment induced an increase in the number of proliferative cells in the sensory epithelium (gentamicin-treated, $12.60 \pm 1.99, n=5$ vs 15 DIV control, $5.40 \pm 0.75, n=5, p<0.01$; Fig. 6). However, the total number of proliferative cells was far below the number of recovered hair cells (see Fig. 4). When gentamicin-treated cultures were maintained in the presence of $15 \mu \mathrm{M}$ aphidicolin, cell proliferation in the sensory epithelium of utricular whole-mount cultures was significantly inhibited, and number of BrdU-positive cells were minimal (gentamicin and aphidicolin cotreated, $2.40 \pm 0.88, n=$ $5, p<0.01$ compared with cultures treated with gentamicin alone; Fig. 6). Thus, the reappearance of stereociliary bundles does not appear to require cell proliferation.

Tritiated thymidine autoradiography of the gentamicin-treated cultures was in good agreement with the BrdU immunocytochemistry. First, the majority of the mitotic cells were situated in the connective tissue underlying the sensory epithelium (Fig. 7A). Second, the number of mitotic cells in the sensory epithelium was small and much lower than the number of recovered hair cells. A small number of supporting cells located in the deep layers of the sensory epithelium were labeled (Fig. $7 A, B$ ). There were considerably fewer labeled supporting cells as compared with labeled 


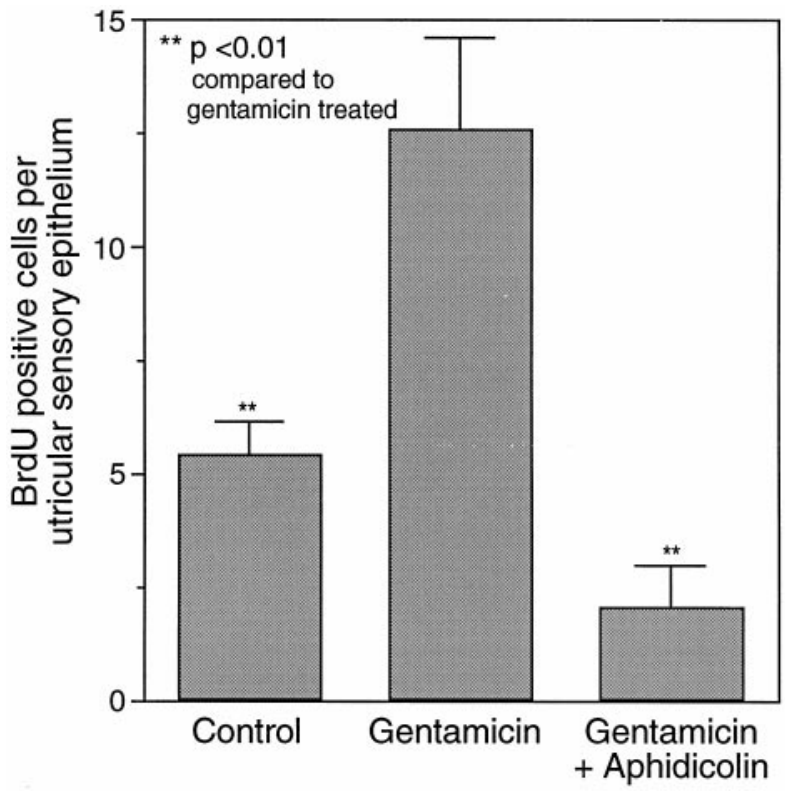

Figure 6. Cell counts of BrdU-positive cells in cryostat sections of utricular explant cultures. The cultures were maintained for 15 DIV. Gentamicin treatment started in 2 DIV cultures for $2 \mathrm{~d}$. BrdU or BrdU and aphidicolin was included in the culture medium immediately after $2 \mathrm{~d}$ gentamicin treatment (4 DIV cultures). Note that although gentamicin treatment induces a significant increase in cell proliferation in the sensory epithelium, the number of BrdU-positive cells in the sensory epithelium of the cultures cotreated with aphidicolin and gentamicin is very limited.

connective tissue cells. In addition, only few cells in the hair cell layer had incorporated tritiated thymidine (Fig. 7C). Because the nuclei of cells undergoing division might relocate within the sensory epithelium, the cells that have incorporated tritiated thymidine in the hair cell layer may not represent real hair cells. The cell count of total tritiated thymidine labeled cells in these cultures is shown in Table 1. Observations from the experiments with either aphidicolin or cell proliferation markers confirm the notion that most of the recovered hair cells were not derived from mitotic cells in the sensory epithelium, but rather from a nonproliferative process.

\section{Gentamicin-induced apoptosis mainly occurs during the treatment period, but is minimal after treatment}

Previous studies have reported apoptosis as a mechanism for gentamicin ototoxicity in the inner ear (Li et al., 1995; Kil et al., 1997; Lang and Liu, 1997; Nakagawa et al., 1997). To determine the kinetics of apoptosis in the utricular explant cultures during and after gentamicin treatment, we performed TUNEL analysis of control and gentamicin-treated cultures at various time points. Cell counts of TUNEL-positive cells in these cultures are shown in Figure $8 C$. There was only a low degree of ongoing apoptosis in the sensory epithelium of control cultures, including those maintained for 15 DIV (Fig. $8 A$ ), suggesting that the cultures were maintained in good condition without much deterioration (see also Fig. 3C,D). Gentamicin treatment induced a significant increase of apoptosis in the sensory epithelium (Fig. 8B). However, when the cultures were returned to normal medium, the levels of apoptosis in gentamicin-treated cultures were similar to those of control cultures (Fig. 8C). Gentamicin-induced apoptosis in the sensory epithelium mainly occurred during the $2 \mathrm{~d}$ treatment period, and additional cell death was minimal $(3.75 \pm 1.93$ and $3.25 \pm 0.48$ TUNEL-positive cells per sensory epithelium for
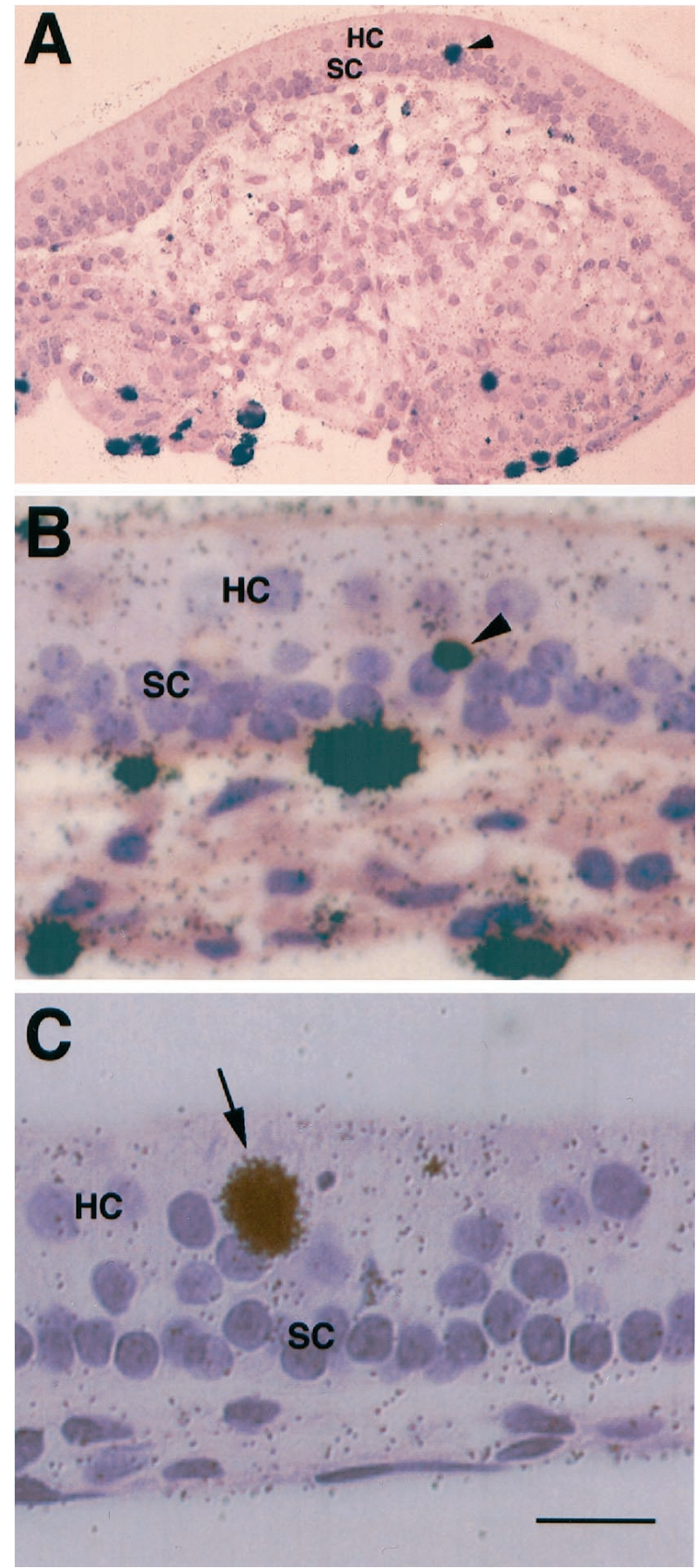

Figure 7. Autoradiographic micrographs of gentamicin-treated utricular explant cultures. Tritiated thymidine and gentamicin were added simultaneously to the 2 DIV cultures. The cultures were fixed in $10 \%$ neutral buffered formalin at $11 \mathrm{~d}$ after gentamicin treatment and processed for paraffin section and autoradiography. $A, B$, Low and high magnification micrographs of two cultures, respectively, showing the incorporation of tritiated thymidine in supporting cell nuclei (arrowheads), which are located in the deep layers of sensory epithelium. Note that as compared with the mitotic cells in the connective tissue underlying the sensory epithelium, the number of mitotic cells in the sensory epithelium is very low. $C$, High magnification micrograph of a culture showing the incorporation of tritiated thymidine in a cell (arrow) located in the lumenal layer that is normally occupied by hair cells in the sensory epithelium. HC, Hair cells; $S C$, supporting cells. Scale bar: $A, 100 \mu \mathrm{m} ; B, C, 25 \mu \mathrm{m}$. 


\begin{tabular}{|c|c|c|c|}
\hline \multirow{2}{*}{$\begin{array}{l}\text { Explant } \\
\text { preparation } \\
\text { number }\end{array}$} & \multicolumn{2}{|c|}{ Sensory epithelium } & \multirow{2}{*}{$\begin{array}{l}\text { Cells in } \\
\text { connective } \\
\text { tissue }\end{array}$} \\
\hline & $\begin{array}{l}\text { Superficial layer } \\
\text { (Hair cell layer) }\end{array}$ & $\begin{array}{l}\text { Deep layer (support- } \\
\text { ing cell layer) }\end{array}$ & \\
\hline 1 & 0 & 0 & 676 \\
\hline 2 & 1 & 8 & 707 \\
\hline 3 & 0 & 5 & 560 \\
\hline 4 & 0 & 4 & 181 \\
\hline 5 & 2 & 16 & 422 \\
\hline 6 & 0 & 12 & 243 \\
\hline 7 & 1 & 4 & 560 \\
\hline 8 & 0 & 7 & 157 \\
\hline
\end{tabular}

The same procedures described in Figure 7 were followed. The total numbers of labeled nuclei in the sensory epithelium (including supporting cell layer and hair cell layer) and in the underlying connective tissue were counted with an ocular grid in a Zeiss Axiophot microscope with a 20 or $40 \times$ lens.

the cultures, 7 and $11 \mathrm{~d}$ after gentamicin treatment, respectively). These observations suggest that apoptosis after gentamicin treatment does not necessarily result in a significant loss of hair cells and supporting cells.

\section{DISCUSSION}

It is important to note that most previous studies on hair cell regeneration have relied on recovery and regeneration of hair cell stereociliary bundles that are assessed by classic histology using light and electron microscopy (Forge et al., 1993; Warchol et al., 1993; Weisleder and Rubel, 1993) or via the use of phalloidin staining of stereociliary bundles in organotypic cultures (Abdouh et al., 1993; Lefebvre et al., 1993; Chardin and Romand, 1995; Zheng and Gao, 1996). These techniques neither allow an analysis of hair cell body integrity nor do they permit accurate counts of remaining hair cells. In the present experiments, we took advantage of an antibody that recognizes a cytoplasmic antigen, calretinin. The anti-calretinin antibody labels the entire hair cell (Dechesne et al., 1994; Zheng and Gao, 1997). Our study provides immunocytochemical evidence that many hair cells in rat utricles can survive such a gentamicin treatment although their stereociliary bundles are lost. These partially damaged hair cells can survive for at least $11 \mathrm{~d}$ after $2 \mathrm{~d}$ gentamicin treatment. Although the number of stereociliary bundle-bearing cells increases over time after gentamicin treatment, the number of surviving hair cells remains essentially the same. In addition, the present experiments show that cell proliferation and apoptosis are minimal in the sensory epithelium of the cultures after gentamicin treatment, suggesting that the numbers of hair cells and supporting cells in the cultures $2-11 \mathrm{~d}$ after gentamicin treatment are not significantly affected by cell proliferation and/or continued apoptosis. These cell numbers mainly reflect the hair cells and supporting cells that survived the $2 \mathrm{~d}$ gentamicin treatment and persisted after gentamicin treatment. Similarly, long-term persistence of partially damaged hair cells after aminoglycoside treatment is also described in cultured frog ears using another immunocytochemical hair cell marker (Gale and Corwin, 1997). Considered together, these observations favor the model that partially damaged hair cells have the capacity to repair themselves in both mammalian and lower vertebrate systems.

The present findings complement our previous study in utricular epithelial sheet cultures (Zheng and Gao, 1997). In the
A

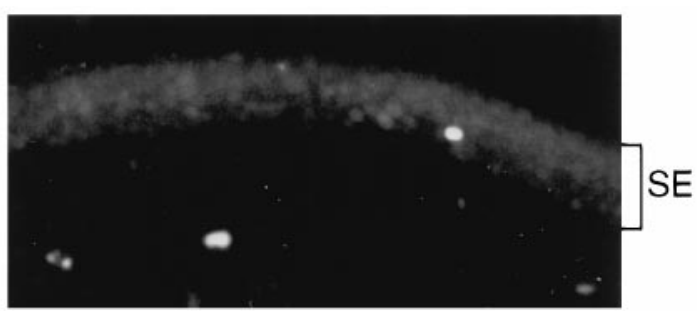

B
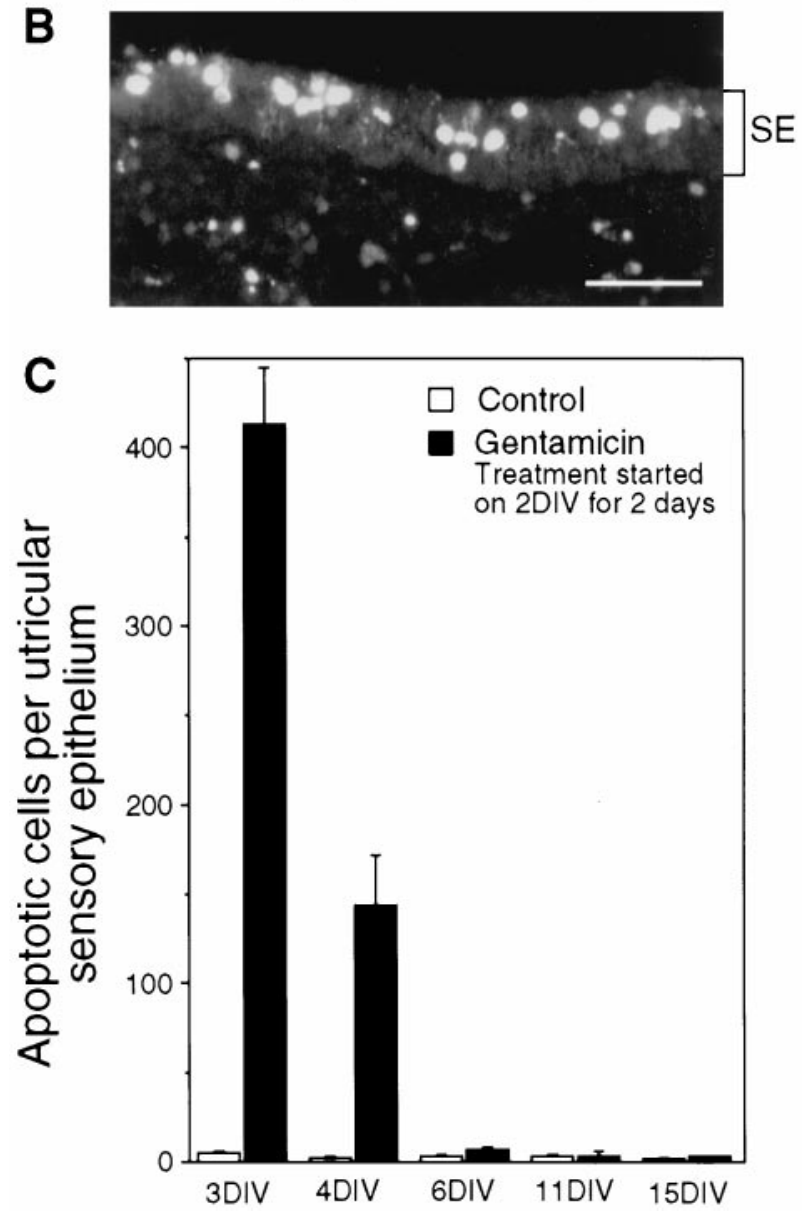

Figure 8. TUNEL analysis in cryostat sections of utricular explant cultures. $A$ and $B$ show a 3 DIV control culture and a culture treated with gentamicin on 2 DIV for $1 \mathrm{~d}$, respectively. Note the greatly enhanced number of TUNEL-positive cells in the sensory epithelium $(S E)$ of the gentamicin-treated culture. $C$, Cell counts of apoptotic cells in the sensory epithelium of gentamicin-treated cultures and parallel control cultures at various time points during and after treatment. Data were collected from four cultures for each of the experimental groups and are expressed as mean \pm SEM. Note that gentamicin-induced apoptosis in the sensory epithelium mainly occurs during the $2 \mathrm{~d}$ treatment period, and additional cell death is minimal when the cultures are returned to normal medium. Scale bar: $A, B, 50 \mu \mathrm{m}$.

utricular epithelial sheet cultures, a considerable number $(23 \%)$ of hair cells survive after an even higher concentration of gentamicin treatment $(3 \mathrm{~mm})$. When utricular epithelial sheet cultures are maintained for an additional 7-11 d after gentamicin treatment in the presence of a mitotic tracer (BrdU), double labeling with calretinin antibody and BrdU antibody reveals that the number of presumptive new hair cells is extremely low: less than one mitotic progenitor cell per utricular sheet differentiates into a calretinin-positive cell within 2 weeks after gentamicin treatment in culture. The very low frequency of proliferation-mediated 
production of new hair cells and the existence of high numbers of partially damaged hair cells after gentamicin treatment in both the utricular epithelial sheet and utricular whole-mount cultures are consistent with the idea that self repair of partially damaged hair cells, rather than supporting cell proliferation-mediated production of new hair cells, makes an important contribution to the spontaneous hair cell regeneration and recovery seen in the mammalian inner ear.

Although caution has to be exercised when in vitro findings are extended to in vivo situations, the histological, cell proliferation, and TUNEL analyses presented here support the notion that the utricular whole-mount cultures represent a system close to in vivo settings. Histological examinations of the 15 DIV control cultures and cultures that are allowed to recover after gentamicin treatment show a relatively good integrity of laminar layers, including hair cell and supporting cell layers. The observations that cell proliferation is very limited and hair cell numbers remain unchanged in 15 DIV control cultures are consistent with previous findings that virtually all hair cells are born by P3 (Ruben, 1967; Sans and Chat, 1982; Zheng and Gao, 1997). TUNEL study reveals only a very small number of apoptotic cells within the sensory epithelium of the 15 DIV cultures, suggesting a very limited tissue deterioration. In addition, the organotypic cultures of utricular whole mounts keep the relatively intact threedimensional architecture in which cell-cell interactions can be maintained. Such cell-cell interactions might be very important for hair cell recovery to occur (Stone et al., 1996).

The lack of a significant reduction in the number of supporting cells and the very low levels of prolonged apoptosis after $2 \mathrm{~d}$ gentamicin treatment in the present experiments suggest that the phenotypic conversion of supporting cells (Adler and Raphael, 1996; Baird et al., 1996; Roberson et al., 1996; Adler et al., 1997; Li and Forge, 1997; Steyger et al., 1997) does not make a major contribution to the recovered number of stereociliary bundlebearing cells. When the stereociliary bundles, which characterize hair cells, are lost, it is morphologically difficult to determine whether it is the partially damaged hair cells or the supporting cells that are the "transitional cells" during conversion into hair cells (Li and Forge, 1997; Forge et al., 1998). Using an immunocytochemical hair cell marker, calretinin antibody, and electron microscopic analysis, we identified the presence of partially damaged hair cells that do not bear stereociliary bundles. The bundleless hair cells might in fact represent the phenotype of the cells that have been proposed as "the transitional cells" in the supporting cells conversion model ( $\mathrm{Li}$ and Forge, 1997; Forge. et al., 1998). Our experiments, on the other hand, do not necessarily exclude the model of phenotypic conversion of supporting cells because a low rate of the conversion of supporting cells into hair cells may be masked by the large number of overall supporting cells and low level of continued apoptosis in these cultures. Identifying the contribution of "conversion" or "self-repair" to hair cell recovery is dependent on the indirect approach of supporting cell counts. Although cell proliferation and continued cell death in the sensory epithelium after gentamicin treatment might favor the model of supporting cell conversion, cell proliferation and TUNEL analysis showed that the numbers of proliferative and apoptotic cells are minimal in the sensory epithelium and cannot match the number of recovered hair cells. Using specific markers for supporting cells in conjunction with markers for immature hair cells would help verify the presence of "the transitional supporting cells" that might express both supporting and hair cell markers. Unfortunately, currently there is no sup- porting cell-specific marker available for mammalian inner ears. Parallel work on cultured bullfrog ears by Corwin and coworkers (Gale and Corwin, 1997; J. Gale, J. Meyers, and J. Corwin, unpublished observations) has also provided electron microscopic evidence that gentamicin-damaged hair cells survive for at least $7 \mathrm{~d}$ and grow new stereociliary bundles. These results support the self-repair model that we propose here in mammals. In addition, electron microscopic studies of neonatal mouse cochlear explant cultures have suggested that stereociliary bundle repair may occur in hair cells after mechanically injured explants (Sobkowicz et al., 1992, 1995, 1997). Because hair cells in the apical turn are more resistant to noise and ototoxic damage than those in the basal and middle turns in the mammalian cochlea (Chardin and Romand, 1995), partially damaged hair cells in the apical turn may have the potential to repair their stereociliary bundles. This self-repair of surviving hair cells could also be the mechanism for the hair cell regeneration reported in postnatal rat cochleae in vitro and in vivo after aminoglycoside treatment (Lefebvre et al., 1993; Chardin and Romand, 1995; Lenoir and Vago, 1996, 1997; Romand et al., 1996; Zine and de Ribaupierre, 1998).

Taken together, the present experiments provide further supporting evidence that there is a low degree of hair cell "recovery" after injury in mammalian inner ears (Forge et al., 1993; Warchol et al., 1993; Tanyeri et al., 1995; Yamane et al., 1995; Li and Forge, 1997; Zheng and Gao, 1997). There are currently three proposed mechanisms that could contribute to the hair cell recovery process: (1) supporting cell proliferation-mediated production of new hair cells, (2) phenotypic conversion of nonproliferative supporting cells into hair cells, and (3) intracellular repair of partially damaged hair cells. The present study provides strong experimental evidence that intracellular self-repair of partially damaged hair cells is an important contributor to the spontaneous recovery of hair cells seen in the mammalian inner ear. In addition, the present observations also suggest that there may be a therapeutic time window in which certain grow th factors may facilitate the self-repair (or delay/rescue the cell death) process (Keithley et al., 1998; Staecker and Van De Water, 1998; Zine and de Ribaupierre, 1998).

\section{REFERENCES}

Abdouh A, Despres G, Romand R (1993) Hair cell overproduction in the developing mammalian cochlea in culture. NeuroReport 5:33-36.

Adler HJ, Raphael Y (1996) New hair cells arise from supporting cell conversion in the acoustically damaged chick inner ear. Neurosci Lett 205:17-20.

Adler HJ, Komeda M, Raphael Y (1997) Further evidence for supporting cell conversion in the damaged avian basilar papilla. Int J Dev Neurosci 15:375-385.

Baird RA, Steyger PS, Schuff NR (1996) Mitotic and nonmitotic hair cell regeneration in the bullfrog vestibular otolith organs. Ann NY Acad Sci 781:59-70.

Balak KJ, Corwin JT, Jones JE (1990) Regenerated hair cells can originate from supporting cell progeny: evidence from phototoxicity and laser ablation experiments in the lateral line system. J Neurosci 10:2502-2512.

Baloh R, Honrubia V (1990) Clinical neurophysiology of the vestibular system. Philadelphia: F.A. Davis Co.

Chardin S, Romand R (1995) Regeneration and mammalian auditory hair cells. Science 267:707-711.

Corwin J, Cotanche D (1988) Regeneration of sensory hair cells after acoustic trauma. Science 240:1772-1774.

Corwin JT, Oberholtzer JC (1997) Fish n' chicks: model recipes for hair-cell regeneration? Neuron 19:951-954.

Corwin JT, Warchol ME, Saffer LD, Finley JE, Gu R, Lamber PR (1996) Growth factors as potential drugs for the sensory epithelia of the ear. Ciba Foundation Symposium 196:167-182; discussion 182-187.

Cotanche DA, Lee KH (1994) Regeneration of hair cells in the vestibu- 
locochlear system of birds and mammals. Curr Opin Neurobiol 4:509-514.

Dechesne CJ, Rabejac D, Desmadryl G (1994) Development of calretinin immunoreactivity in the mouse inner ear. J Comp Neurol 346:517-529.

Dublin WB (1976) Fundamentals of sensorineural auditory pathology. Springfield, IL: C. C. Thomas.

Forge A, Li L, Corwin JT, Nevill G (1993) Ultrastructural evidence for hair cell regeneration in the mammalian inner ear. Science 259:1616-1619.

Forge A, Li L, Nevill G (1998) Hair cell recovery in the vestibular sensory epithelia of mature guinea pigs. J Comp Neurol 397:69-88.

Gale J, Corwin J (1997) Hair cell repair after antibiotic damage: a time-lapse and culture study in the bullfrog saccules. Soc Neurosci Abstr 23:1822.

Hudspeth AJ (1989) How the ear's works work. Nature 341:397-404.

Hudspeth AJ (1997) How hearing happens. Neuron 19:947-950.

Jones JE, Corwin JT (1996) Regeneration of sensory cells after laser ablation in the lateral line system: hair cell lineage and macrophage behavior revealed by time-lapse video microscopy. J Neurosci 16:649-662.

Keithley E, Ma C, Ryan A, J-C L, Magal E (1998) GDNF protects the cochlea against noise damage. NeuroReport 9:2183-2187.

Kil J, Warchol ME, Corwin JT (1997) Cell death, cell proliferation, and estimates of hair cell life spans in the vestibular organs of chicks. Hear Res 114:117-126.

Lambert P (1994) Inner ear hair cell regeneration in a mammal: identification of a triggering factor. Laryngoscope 104:701-717.

Lang H, Liu C (1997) Apoptosis and hair cell degeneration in the vestibular sensory epithelia of the guinea pig following a gentamicin insult. Hear Res 111:177-184.

Lefebvre PP, Malgrange B, Staecker H, Moonen G, Van de Water TR (1993) Retinoic acid stimulates regeneration of mammalian auditory hair cells. Science 260:692-695.

Lenoir M, Vago P (1996) Morphological indications of hair cell neodifferentiation in the organ of Corti of amikacin treated rat pups. Comptes Rendus de 1 Academie des Sciences - Serie Iii, Sciences de la Vie 319:269-76.

Lenoir M, Vago P (1997) Does the organ of Corti attempt to differentiate new hair cells after antibiotic intoxication in rat pups? Int J Dev Neurosci 15:487-495.

Li L, Forge A (1995) Cultured explants of the vestibular sensory epithelia from adult guinea pigs and effects of gentamicin: a model for examination of hair cell loss and epithelial repair mechanisms. Aud Neurosci 1:111-125.

Li L, Forge A (1997) Morphological evidence for supporting cell to hair cell conversion in the mammalian utricular macula. Int J Dev Neurosci 15:433-446.

Li L, Nevill G, Forge A (1995) Two modes of hair cell loss from the vestibular sensory epithelia of the guinea pig inner ear. J Comp Neurol 355:405-417.

Nadol J (1993) Hearing loss. N Engl J Med 329:1092-1102.

Nakagawa T, Yamane H, Shibata S, Nakai Y (1997) Gentamicin ototoxicity induced apoptosis of the vestibular hair cells of guinea pigs. Eur Arch Oto-Rhino-Laryngol 254:9-14.

Pickles JO, Corey DP (1992) Mechanoelectrical transduction by hair cells. Trends Neurosci 15:254-259.

Roberson D, Kreig C, Rubel E (1996) Light microscopic evidence that direct transdifferentiation gives rise to new hair cells in regenerating avian auditory epithelium. Aud Neurosci 2:195-205.

Romand R, Chardin S, Le Calvez S (1996) The spontaneous appearance of hair cell-like cells in the mammalian cochlea following aminoglycoside ototoxicity. NeuroReport 8:133-137.

Rubel EW, Dew LA, Roberson DW (1995) Mammalian vestibular hair cell regeneration. Science 267:701-707.

Ruben RJ (1967) Development of the inner ear of the mouse: a radioautographic study of terminal mitosis. Acta Otolaryngol [Suppl] 220:1-44.
Ryals BM, Rubel EW (1988) Hair cell regeneration after acoustic trauma in adult Coturnix quail. Science 240:1774-1776.

Sans A, Chat M (1982) Analysis of temporal and spatial patterns of rat vestibular hair cell differentiation by tritiated thymidine radioautography. J Comp Neurol 206:1-8.

Sobkowicz H, August BK, Slapnick SM (1992) Epithelial repair following mechanical injury of the developing organ of Corti in culture: an electron microscopic and auto radiographic study. Exp Neurol 115:44-49.

Sobkowicz HM, Slapnick SM, August BK (1995) The kinocilium of auditory hair cells and evidence for its morphogenetic role during the regeneration of stereocilia and cuticular plates. J Neurocytol 24:633-653.

Sobkowicz HM, August BK, Slapnick SM (1997) Cellular interactions as a response to injury in the organ of Corti in culture. Int J Dev Neurosci 15:463-485.

Staecker H, Van De Water T (1998) Factors controlling hair-cell regeneration/repair in the inner ear. Curr Opin Neurobiol 8:480-487.

Steyger PS, Burton M, Hawkins JR, Schuff NR, Baird RA (1997) Calbindin and parvalbumin are early markers of non-mitotically regenerating hair cells in the bullfrog vestibular otolith organs. Int $\mathbf{J}$ Dev Neurosci 15:417-432.

Stone JS, Cotanche DA (1994) Identification of the timing of S phase and the patterns of cell proliferation during hair cell regeneration in the chick cochlea. J Comp Neurol 341:50-67.

Stone JS, Leano SG, Baker LP, Rubel EW (1996) Hair cell differentiation in chick cochlear epithelium after aminoglycoside toxicity: in vivo and in vitro observations. J Neurosci 16:6157-6174.

Stone JS, Oesterle EC, Rubel EW (1998) Recent insights into regeneration of auditory and vestibular hair cells. Curr Opin Neurol 11:17-24.

Tanyeri H, Lopez I, Honrubia V (1995) Histological evidence for hair cell regeneration after ototoxic cell destruction with local application of gentamicin in the chinchilla crista ampullaris. Hear Res 89:194-202.

Warchol ME, Corwin JT (1996) Regenerative proliferation in organ cultures of the avian cochlea: identification of the initial progenitors and determination of the latency of the proliferative response. J Neurosci 16:5466-5477.

Warchol ME, Lambert PR, Goldstein BJ, Forge A, Corwin JT (1993) Regenerative proliferation in inner ear sensory epithelia from adult guinea pigs and humans. Science 259:1619-22.

Warchol ME, Lambert PR, Goldstein BJ, Forge A, Corwin JT (1995) Response to: mammalian vestibular hair cell regeneration. Science 267:704-706.

Weisleder P, Rubel EW (1993) Hair cell regeneration after streptomycin toxicity in the avian vestibular epithelium. J Comp Neurol 331:97-110.

Yamane H, Nakagawa T, Iguchi H, Shibata S, Takayama M, Nishimura K, Nakai Y (1995) In vivo regeneration of vestibular hair cells of guinea pig. Acta Otolaryngol Suppl (Stockh) 520:174-177.

Zheng JL, Gao W-Q (1996) Differential damage to auditory neurons and hair cells by ototoxins and neuroprotection by specific neurotrophins in rat cochlear organotypic cultures. Eur J Neurosci 8:1897-1905.

Zheng JL, Gao W-Q (1997) Analysis of rat vestibular hair cell development and regeneration using calretinin as an early marker. J Neurosci $17: 8270-8282$.

Zheng JL, Stewart RR, Gao W-Q (1995) Neurotrophin-4/5 enhances survival of cultured spiral ganglion neurons and protects them from cisplatin neurotoxicity. J Neurosci 15:5079-5087.

Zheng JL, Helbig C, Gao W-Q (1997) Induction of cell proliferation by fibroblast and insulin-like growth factors in pure rat inner ear epithelial cell cultures. J Neurosci 17:216-226.

Zheng JL, Lewis A, Gao W-Q (1998) Establishment of conditionally immortalized rat utricular epithelial cell lines using a retrovirusmediated gene transfer technique. Hear Res 117:13-23.

Zine A, de Ribaupierre F (1998) Replacement of mammalian auditory hair cells. NeuroReport 9:263-268. 